\title{
Extreme High Yield of Tropical Rice Grown Without Fertilizer on Acid Sulfate Soil in South Kalimantan, Indonesia
}

\author{
Erry Purnomo ${ }^{1}$, Yasuyuki Hashidoko ${ }^{2}$, Toshihiro Hasegawa ${ }^{3}$ and Mitsuru Osaki ${ }^{2}$
}

Received 22 May 2009 / accepted 4 December 2009

\begin{abstract}
Extreme High Yield of Tropical Rice Grown Without Fertilizer on Acid Sulfate Soil in South Kalimantan, Indonesia (E Purnomo, Y Hashidoko, T Hasegawa and M Osaki): Local rice varieties are commonly grown by the farmers located in acid sulfate soil area of South Kalimantan. In South Kalimantan, more than 100 local rice varieties can be found. In 1999, a farmer found one hill (with 5 tillers) rice plant near a canal, later called Padi Panjang. The rice had panicle length of $50 \mathrm{~cm}$. The panicle length of common local rice varieties are $25 \mathrm{~cm}$. Since the finding, the farmer multiplied the seed for 3 years to get a reasonable amount of seeds for nearby farmers to use. In 2004, there were 25 farmers grow the Padi Panjang by themselves. Their paddocks are widely spread out in Aluh-Aluh and Gambut districts. We take this opportunity to investigate yield variation of the Padi Panjang that may be affected by soil properties variability. Ten paddocks out of the 25 paddock were selected. At harvest time (in July-August), we measured the rice yield and collected soil sample from the 10 paddocks. We found that the soil condition in the selected paddocks were marginally suitable for growing improved rice. Without fertilizer, however, the rice yield varied from 3.21 to $8.09 \mathrm{Mg} \mathrm{ha}^{-1}$. We also observed that the rice yield variations associated with tillers number. We did not find any correlation between rice yields with some selected soil properties, except it was observed that the tillers number was negatively correlated with soil electrical conductivity (EC). The extreme yield of Padi Panjang might be explained the involvement of N fixing bacteria and P solubilizing bacteria, large rooting system and the ability of Padi Panjang root in modifying the rhizosphere soil.
\end{abstract}

Keywords: Acid sulphate soil, local rice variety, low input sustainable agriculture, South Kalimantan

\section{INTRODUCTION}

Generally, the yield of local rice varieties are considered low compared to improved rice. In addition, farmers do not like to grow local varieties due to the longer growing period (Anonymous 2008b). They could only grow once a year. However, local varieties are commonly grown by the farmers located in acid sulfate soil area of South Kalimantan. In South Kalimantan, more than 100 local rice varieties can be found.

In a marginally soil condition for growing improved rice, the local rice varieties produce a reasonable yield without fertilizer. Work of Hasegawa et al. (2001) had shown that there some local rice varieties that yielded more than $3 \mathrm{Mg} \mathrm{ha}^{-1}$ without fertilizer after last transplanting. In addition, survey work of Hasegawa et al. (2004) of 60 paddocks in this area, grain yields averaged $2.6 \mathrm{Mg} \mathrm{ha}^{-1}$ and $10 \%$ of the paddocks studied exceeded $4 \mathrm{Mg} \mathrm{ha}^{-1}$. The absence use of fertilizer could be explained by the involvement microorganisms anchored on the rizosphere as suggested by Hashidoko et al. (2002) Purnomo et al. (2006b) and Su et al. (2007).

In 2003, we were surprised by information that there was local rice variety with a panicle length of $50 \mathrm{~cm}$. The panicle length of common local rice varieties are $25 \mathrm{~cm}$. In 2004, 25 farmers grew the

\footnotetext{
${ }^{1}$ Program Study of Natural Resource and Environmental Management, Lambung Mangkurat University. Present address: Center for Research and Mine Closure Developments PT Adaro Indonesia, Hauling Road KM 73 Wara, Tabalong, Kalimatan Selatan; E-mail: erry_purnomo@ptadaro.com

${ }^{2}$ Graduate Study of Agriculture, Hokkaido University, Sapporo, Japan

${ }^{3}$ Atmospheric Impact Units, Department of Global Resources, National Institute for Agro-Environmental Sciences, 3-1-3 Kannondai, Tsukuba, Ibaraki 305-8604, Japan.

J Trop Soils, Vol. 15, No. 1, 2010: 33-38

ISSN 0852-257X
} 
newlyfound local rice (later called by padi panjang) by themselves. Their paddocks are widely spread out in Aluh-Aluh and Gambut districts of South Kalimantan. We take this opportunity to investigate the yield variation of the padi panjang and the effect of chemical properties on the yield variation.

\section{MATERIALS AND METHODS}

\section{Study Site}

The study site located in Aluh-Aluh and Gambut Districts of South Kalimantan. We selected 10 paddocks out of 25 farmers who grew padi panjang in year 2004. The paddock selection was based on the need to have a vary soil chemical properties among the paddocks selected. Figure 1 shows the distribution of paddocks in the study area.

\section{Rice Cultivation Technique}

Local varieties are planted widely under a unique traditional cultural practice as described in Figure 2

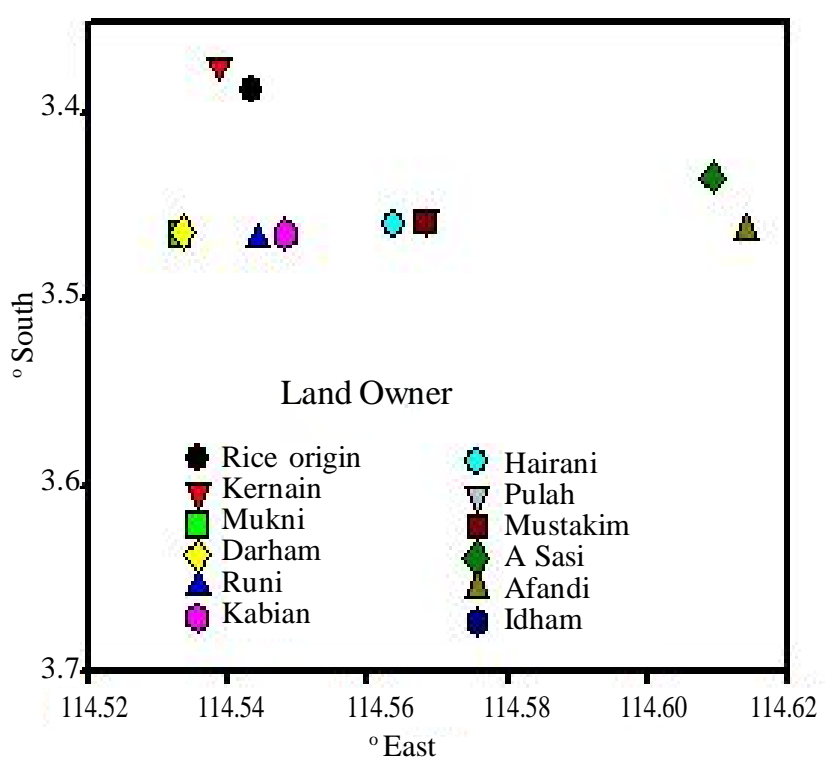

Figure 1. Paddocks distribution in the study area.
(Hasegawa et al. 2004). The crop calendar is developed because they are believed to adapt well to unfavorable edaphic conditions, unpredictable water levels and pest cycle.

\section{Sampling Technique}

At harvest time (in July-August 2004), plant and soil samples were collected. The plant was collected

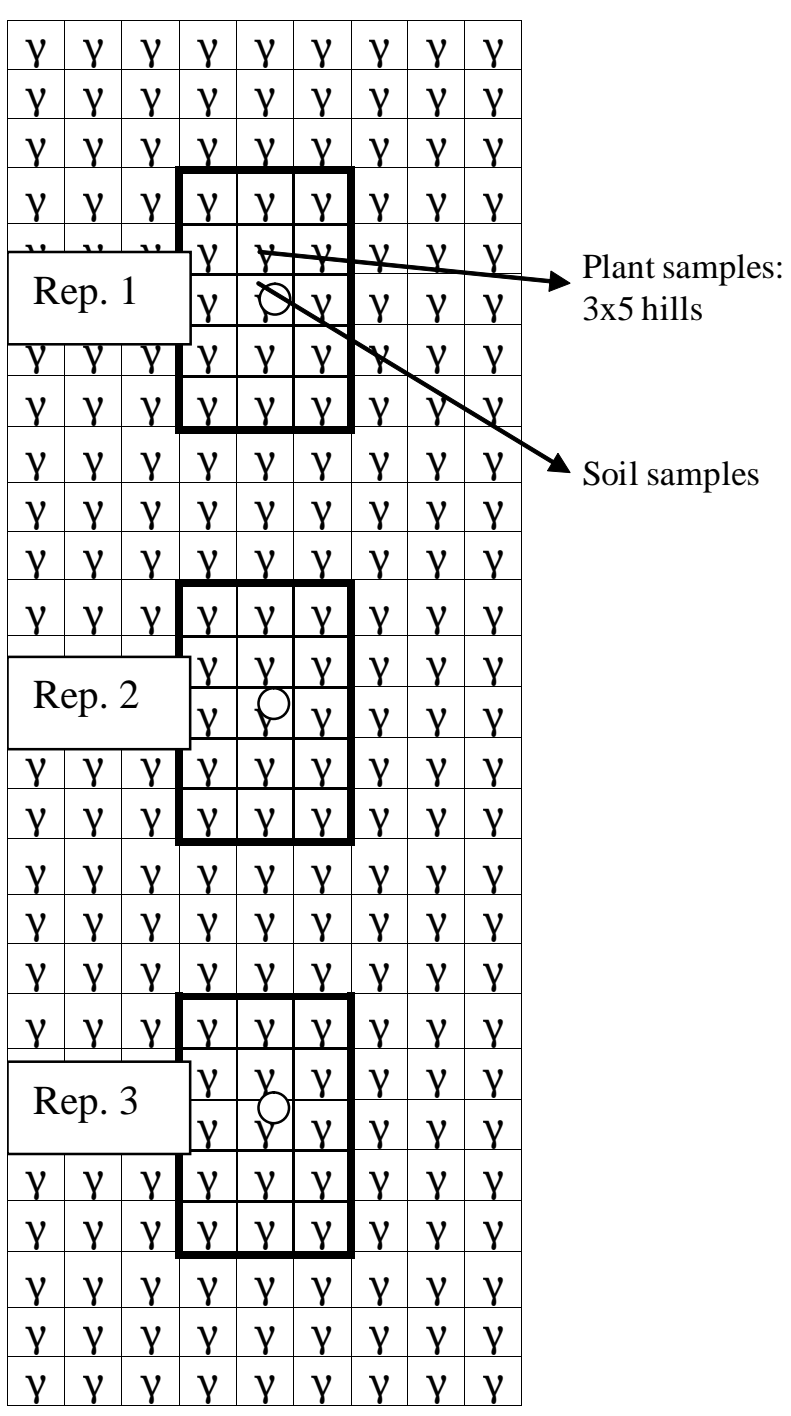

Figure 3. Layout of sampling in each paddock.

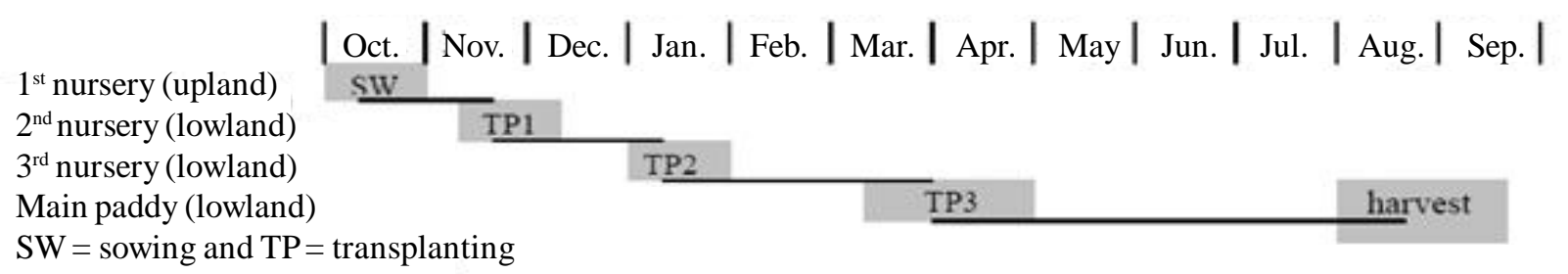

Figure 2. Atypical crop calendar of traditional transplanting practice in South Kalimantan (Hasegawa et al. 2004). 
from $3 \times 5$ hills. There were 3 replicates for each paddock (Figure 3). Soil sample was collected under the rice crop up to $25 \mathrm{~cm}$ depth. As a comparison, other local rice varieties grown near by Padi Panjang were also sampled.

\section{Plant and Soil Analyses}

At harvest time, yield of Padi Panjang was measured. The soil samples collected were analyzed their chemical properties, namely $\mathrm{pH}, \mathrm{EC}$, cation base, mineral $\mathrm{N}, \mathrm{P}_{\text {Brayl }}$, total $\mathrm{N}$ and $\mathrm{C}$. The soil analysis procedures are described in Page et al. (1982).

Standard error of mean was used to show data variation.

\section{RESULTS AND DISCUSSION}

\section{Soil Condition}

Table 1 demonstrates suitability of soil for growing improved rice and the soil chemical constraint. Most of the soil condition the paddocks selected were marginally suitable for the improved rice. This means that to obtain good yield a high input technology should be employed, such as, fertilizer and soil amendment inputs. Unfortunately, most farmers can not afford to buy such input. In addition, unpredictable water level forces most farmers in this area are not interested to grow improved rice.

Table 1. Soil condition of the selected paddocks.

\begin{tabular}{|c|c|c|c|c|c|c|}
\hline Village & Paddock owner & Suitability ${ }^{1)}$ & \multicolumn{4}{|c|}{ Constraints } \\
\hline Kuin & Kernain & Marginal & & $\mathrm{P}$ & $\mathrm{pH}$ & \\
\hline SP Warga & Darham & Not suitable & & & & $\mathrm{EC}$ \\
\hline SP Warga & Mukni & Marginal & & $\mathrm{P}$ & $\mathrm{pH}$ & $\mathrm{EC}$ \\
\hline Bunipah Ujung & Runi & Marginal & & $\mathrm{P}$ & $\mathrm{pH}$ & \\
\hline Bunipah Ujung & Kabian & Marginal & & & $\mathrm{pH}$ & \\
\hline Bunipah Ujung & Khairani & Marginal & & & $\mathrm{pH}$ & \\
\hline Bunipah Bawah & Mustakim & Marginal & & & $\mathrm{pH}$ & \\
\hline Bunipah Bawah & Pulah & Marginal & & & $\mathrm{pH}$ & \\
\hline TS Laut & A Sasi & Marginal & & & $\mathrm{pH}$ & \\
\hline Makmur & Afandi & Marginal & K & & $\mathrm{pH}$ & \\
\hline GT Papuyu & Idham & Marginal & & & $\mathrm{pH}$ & \\
\hline
\end{tabular}

Note: ${ }^{1)}$ for improved rice (Djaenuddin et al. 1995).

Table 2. Padi Panjang yield variation grown at various paddocks.

\begin{tabular}{|c|c|c|c|c|}
\hline Location & Owner & $\begin{array}{l}\text { Yield } \\
\left(\mathrm{Mg} \mathrm{ha}^{-1}\right)\end{array}$ & $\begin{array}{l}\text { Standard } \\
\text { error }\end{array}$ & Note \\
\hline Kuin & Kernain & 7.9 & 0.58 & \\
\hline Sp Warga & Darham & 5.34 & 0.81 & \multirow{4}{*}{$\begin{array}{l}\text { Increase } \\
\text { in distance } \\
\text { from the } \\
\text { main river }\end{array}$} \\
\hline Sp Warga & Mukni & 3.56 & 0.39 & \\
\hline Bunipah Ujung & Runi & 7.4 & 0.34 & \\
\hline Bunipah Ujung & Kabian & 6.13 & 0.21 & \\
\hline Bunipah Ujung & Hairani & 3.21 & 0.44 & \\
\hline Bunipah Bawah & Mustakim & 4.32 & 0.61 & \\
\hline Bunipah Bawah & Pulah & 3.85 & 0.89 & \\
\hline TS darat & A Sasi & 5.98 & 0.99 & \\
\hline Makmur & Afandi & 8.09 & 1.10 & \\
\hline Gt Papuyu & Idham & 5.22 & 0.25 & \\
\hline
\end{tabular}




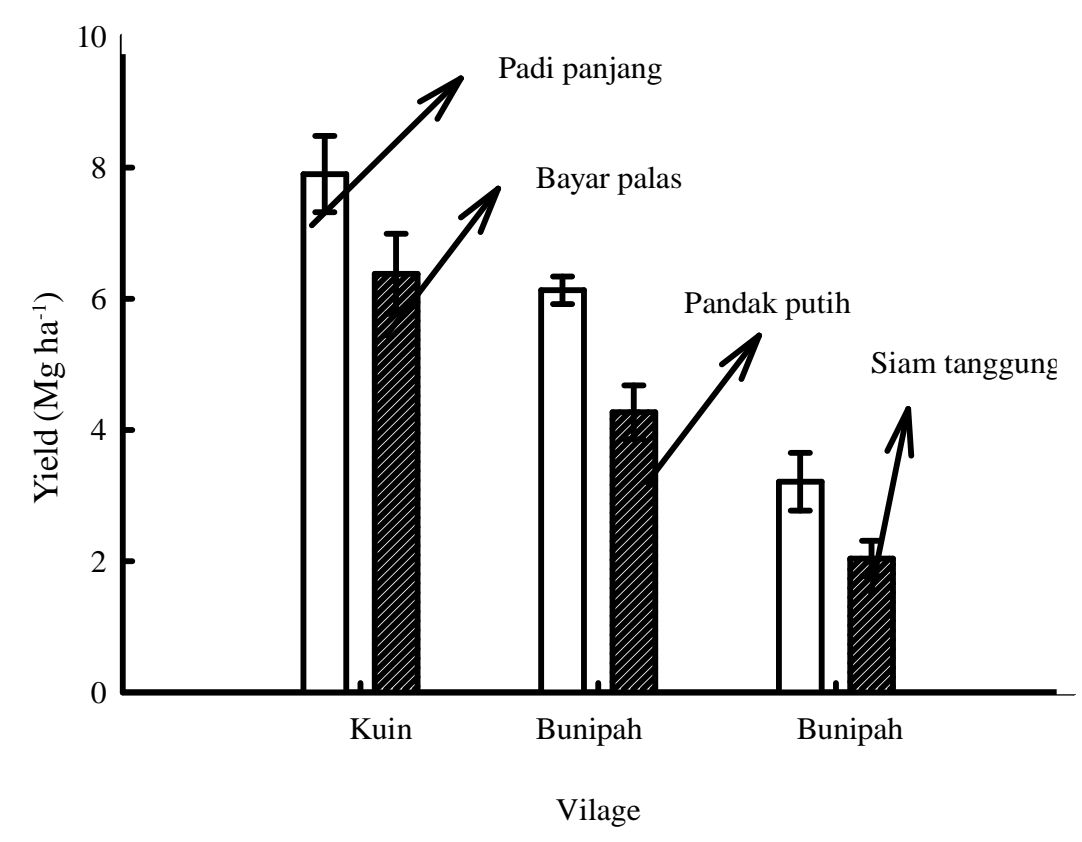

Figure 4. The Padi Panjang yield compared with other local rice varieties. Bars indicate standard error of mean.

\section{Rice Yield}

The rice yields from the selected paddocks are shown in Table 2. The yield varied from 3.2 to 8.09 $\mathrm{Mg} \mathrm{ha}^{-1}$. Compare with the other local rice varieties grown nearby paddocks, the Padi Panjang yield was always higher (Figure 4) and its panicle length had much longer other local rice varieties (Figure 5). Inspite of adverse soil condition, the Padi Panjang produced extreme high yield without fertilizer. This rice yield is much higher than previously observed by Hasegawa et al. (2004). This finding at least shows the important of conserving the local rice varieties. So, the disappearing of genetic pool of local rice (Anonymous 2008a) can be prevented.

\section{Padi Panjang Yield and Soil Properties}

It seems that yield variation of the Padi Panjang variety did not correlate with the soil properties. However, the yield variation had a close association with the tiller number (Figure 6). This relationship is self explanatory. Furthermore, only tillers number was negatively correlated with the EC (Figure 7). It was observed that soil EC of up to $2 \mathrm{dSm}^{-1}$ decreased tillers number of $35 \%$ and may result in decreasing yield of Padi Panjang. As the soil EC increased higher than 2 $\mathrm{dSm}^{-1}$, the tillers number remained the same. Purnomo et al. (2008) observed that other local rice varieties, namely, Pandak Putih and Siam Unus with soil EC of 36

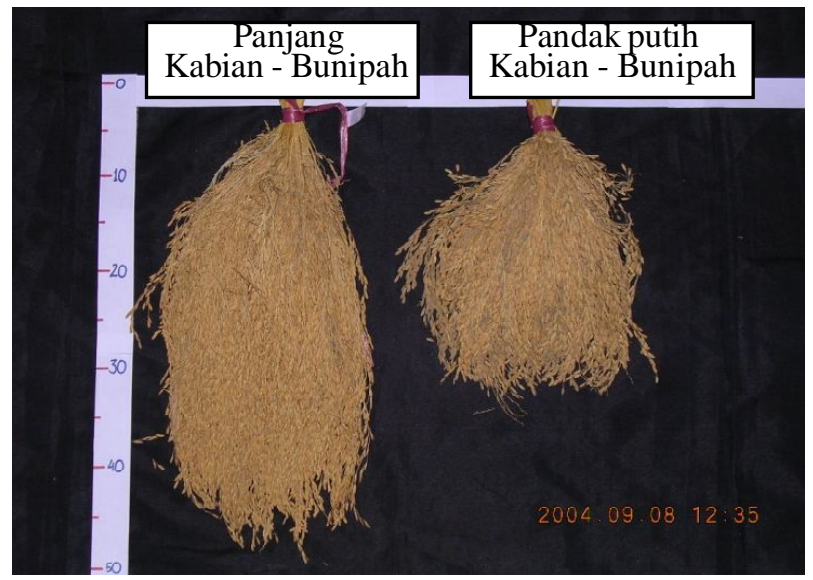

Figure 5. Panicle length of Padi Panjang compared with other local rice variety.

approximately $8 \mathrm{dSm}^{-1}$ yielded 1.55 and $1.96 \mathrm{Mg} \mathrm{ha}^{-1}$, respectively. For the same soil EC, Padi Panjang produced 5.34 Mg ha- ${ }^{-1}$. The Padi Panjang has the potential to be grown on soils with salinity problem.

The lack of relationship between yield of Padi Panjang variety and soil properties may be due to some reasons such as (1) the involvement of $\mathrm{N}$ fixing bacteria (Hashidoko et al. 2002) and $\mathrm{P}$ solubilizing bacteria (Purnomo et al. 2005), (2) large rooting system and (3) the ability of Padi Panjang root in modifying the rhizosphere soil (Purnomo 2008). 


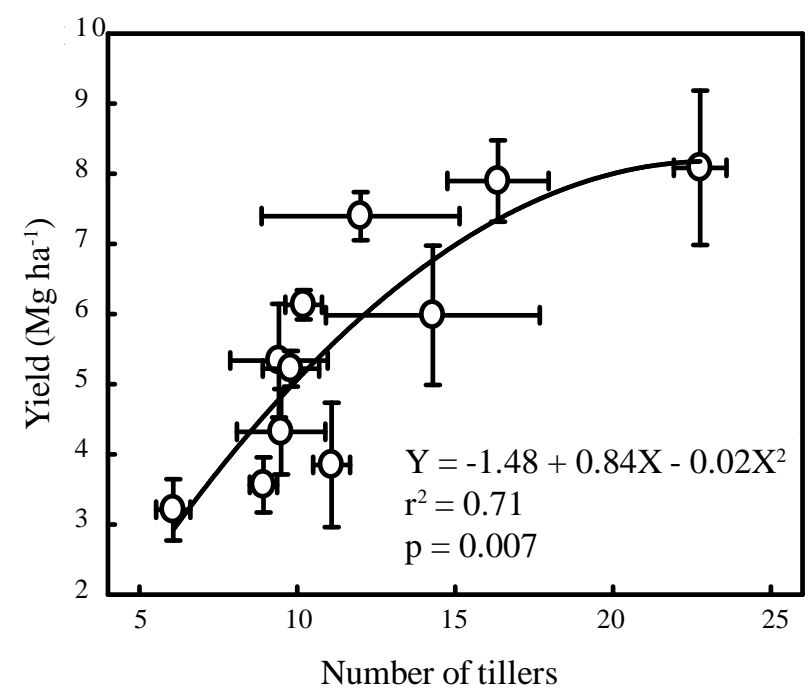

Figure 6. The relationship between tiller number and rice yield. Bars indicate standard error of mean.

\section{CONCLUSIONS}

It can be concluded that inspite of the soil constraints, the yield of Padi Panjang variety grown on acid sulfate soil varied between 3.2 to $8.09 \mathrm{Mg}$ $\mathrm{ha}^{-1}$. It can be pointed out that without fertilizer, the extreme yield obtained indicating that the system is considered as low input sustainable agriculture. It was observed that the rice yield variation related to the number of tillers. There was no significant relationship between soil properties and rice yield variation. However, we observed that tillers number negatively correlated only with soil EC. The lack of correlation between yield and soil properties indicates the need of further research on this line.

It can be pointed out that the finding of Padi Panjang variety not only shows the need of conserving the local rice varieties but also the cultivation system is considered as a low input technology. So, this system is good for the environment.

\section{ACKNOWLEDGMENT}

We would like to thank University of Hokkaido for financing the work. The help of students at the center are highly appreciated. Erry Purnomo thanked PT Adaro Indonesia for providing an excellent environment for working.

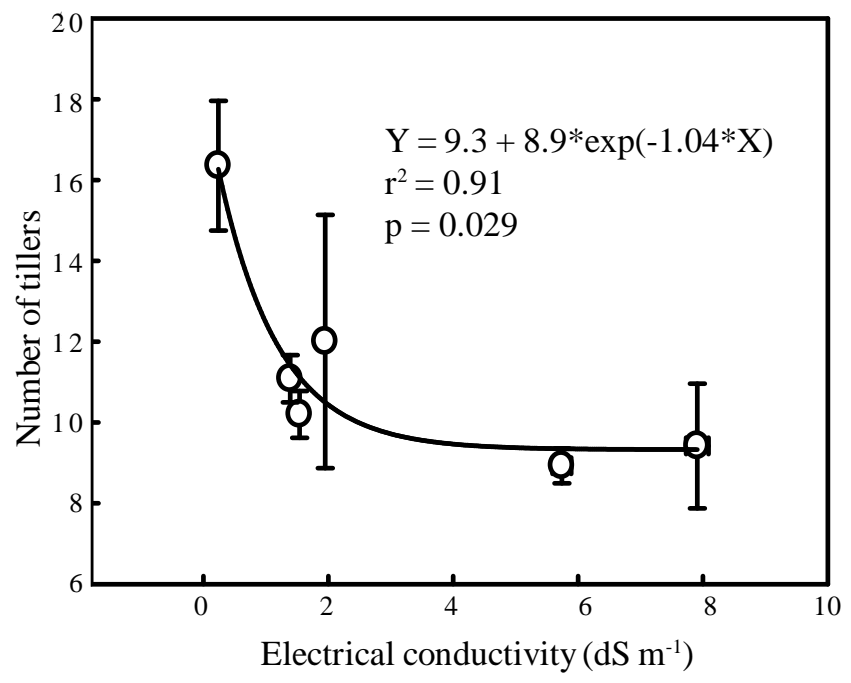

Figure 7. The relationship between soil EC and tiller number. Bars indicate standard error of mean.

\section{REFERENCES}

Anonymous. 2008a. Ribuan Varietas Padi Lokal Hilang. Kompas 15 September 2008.

Anonymous. 2008b. Varietas Padi Lokal Tak Diminati. Kompas 17 September 2008.

Djaenuddin D, Basuni, S Hardjowigeno, H Subagjo, Sukardi, M Ismangun, Ds Marsudi, N Suharta, L Hakim, Widagdo, J Dai, V Suwandi, S Bachri and ER Jordens. 1995. Land Suitability for Agricultural and Silviculture Plants. Laporan Teknis No. 7. Versi 1.0. April 1994. Center for Soil and Agroclimate Research, Bogor. (In Indonesian).

Hasegawa T, E Purnomo and G Rusmayadi. 2001. Establishment of sustainable agro-ecosystems in Kalimantan: A field survey report with reference to rice production in South Kalimantan. In: Anonymous (ed). Environmental Conservation and Land Use Management of Wetland Ecosystem in Southeast Asia. Annual Report for April 2000-March 2001.

Hasegawa T, E Purnomo, Y Hashidoko, M Osaki and G Rusmayadi. 2004. Grain yield and its variation of local rice varieties grown on acid sulphate soil in South Kalimantan. Jap J Crop Sci 73: 220-221.

Hashidoko Y, T Hasegawa, E Purnomo and M Osaki. 2002. Rhizoplane $\mathrm{pH}$ and rhizoplane mikroflora of local rice varieties grown on acid sulphate soil in South Kalimantan. International Symposium on Land Management and Biodiversity in Southeast Asia. Bali, Indonesia. 17-20 September 2002. 
Page AL, RH Miller and DR Keeney. 1982. Methods of Soil Analysis. II. Chemical and Microbiological Properties, $2^{\text {nd }}$ edition, ASA, Madison, Wisconsin. xxiv+, 1159 p.

PurnomoE. 2008. Rhizosphere Function of an Extreme High Tropical Local Rice Variety Grown without Fertilizer on Adverse Soil in South Kalimantan, Indonesia. International Workshop on Rhizosphere Technology in Sustaining Plant Growth in Adverse Soils and Prediction for Carbon Trade 25-26 February 2008, Banjarmasin, South Kalimantan, Indonesia.

Purnomo E, T Hasegawa, Y Hashidoko and M Osaki. 2006. Soil nitrogen supply and local rice nitrogen uptake in unfertilised acid sulphate soil in South Kalimantan. Tropics 15: 349-354.

Purnomo E, M Sarwani, A Jumberi, A Mursyid, T Hasegawa, Y Hashidoko, T Shinano, S Honma and M Osaki. 2005.
Phosphorus nutrition of high yielding local rice varieties grown without fertilizer on acid sulphate soil. Soil Sci Plant Nutr 51: 679-681.

Purnomo E, ML Setiawan, H Halim, D Choiron, R Yulia, T Shinano, Y Hashidoko, T Hasegawa and M Osaki. 2005. Padi lokal, tanpa pupuk dengan hasil 8 ton per hektar. Kompas. 21 September 2005.

Purnomo E, ML Setiawan, N.Yuliani, E Atmaja, M Wahyuni, AR Saidy and M Osaki. 2008. Local rice cultivars grown on swampland in coastal area in South Kalimantan. J Tanah Trop 13: 103-109.

Su Y, T Shinano, E Purnomo and M Osaki. 2007. Growth promotion of rice by inoculation of acid-tolerant, $\mathrm{N}_{2}$ fixing bacteria isolate from acid sulphate paddy soil in South Kalimantan, Indonesia. Tropics 16: 261-274. 